\title{
Comparison anti-oxidant and neuroprotective effects of extra-virgin olive oil, donepezil and rosmarinic acid on aluminum chloride-induced Alzheimer's in rat models
}

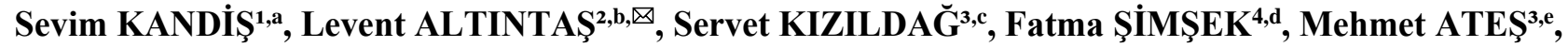 \\ Hasan ALAÇAM ${ }^{5, f}$, Nazan UYSAL ${ }^{1, g}$
}

${ }^{1}$ Department of Physiology, Dokuz Eylül University, Faculty of Medicine, Izmir, Turkey; ${ }^{2}$ Ankara University, Faculty of Veterinary Medicine, Department of Pharmacology and Toxicology, Ankara, TURKEY; ${ }^{3}$ College of Vocational School of Health Services, Dokuz Eylül University, Faculty of Medicine, Izmir, Turkey; ${ }^{4}$ Department of Histology and Embryology, Kâtip Çelebi University, Faculty of Medicine, Izmir, Turkey; ${ }^{5}$ Ahenk Laboratory, Biochemistry Laboratory, Istanbul, Turkey ${ }^{\mathrm{a}}$ ORCID: 0000-0001-8992-7985; ${ }^{\mathrm{b}}$ ORCID: 0000-0002-5148-723X; ' $\mathrm{ORCID:} \mathrm{0000-0003-3565-279X;}$ ${ }^{\mathrm{d}}$ ORCID: 0000-0002-7131-7035; ${ }^{\mathrm{e}}$ ORCID: 0000-0002-2764-6579; ${ }^{\mathrm{f}}$ ORCID: 0000-0003-3807-2926;

g ORCID: 0000-0002-2348-7427

$\triangle$ Corresponding Author: laltintas@ankara.edu.tr

Received date: 28.12.2020 - Accepted date: 16.04.2021

\begin{abstract}
In this study, it was aimed to investigate the effects of EVOO, rosmarinic acid and donepezil in Alzheimer's model to be created with $\mathrm{AlCl}_{3}$ in rats. For this reason, administration of $100 \mathrm{mg} / \mathrm{kg}$ aluminum chloride $\left(\mathrm{AlC}_{3}\right)$ for 15 days to Sprague Dawley adult male rats; donepezil, Extra-virgin olive oil (EVOO) and rosmarinic acid were administered to three different groups for 21 days by applying treatment protocols. With this study, we were able to demonstrate that cognitive impairment has been occurred after 15 days of $\mathrm{AlCl}_{3}$ administration by oral gavage and treatment protocols prevented the occurrence of $\mathrm{AD}$ pathology histopathologically. We also showed that oxidative damage findings which are positively Congo-red stained cell cytoplasm and impaired cell integrity have been observed in serum and hippocampus. Besides, treatment groups showed better cognitive and motor performance, and there was no damage to the cells in control and treatment groups. In the rotarod motor performance test, a significant increase was observed in the donepezil group compared to the $\mathrm{AlCl}_{3}$ group at speeds of 26 and $30 \mathrm{rpm}$. In MVM, on the $5^{\text {th }}$ day of the experiment, a significant increase was observed in the donepezil group compared to the $\mathrm{AlCl}_{3}$ group, as they were spending more time in the hidden platform area. These results show that 15 days of aluminum exposure is effective in creating a moderate Alzheimer's pathology, but further chronic research is necessary to explain the efficiencies of rosmarinic acid and EVOO in treatment.
\end{abstract}

Keywords: Aluminum chloride, Alzheimer, donepezil, EVOO, rosmarinic acid.

\section{Ratlarda alüminyum klorür ile oluşturulmuş Alzheimer modelinde sızma zeytinyağı, donepezil ve rosmarinik asidin antioksidan ve nöroprotektif etkilerinin karşılaştırılması}

Özet: $\mathrm{Bu}$ çalışmada; sıçanlarda $\mathrm{AlCl}_{3}$ ile oluşturulan Alzheimer modelinde, EVOO, rozmarinik asit ve donepezilin etkilerinin araştırılması amaçlanmıştır. Bu sebeple, Sprague Dawley yetişkin erkek sıçanlara 15 gün boyunca $100 \mathrm{mg} / \mathrm{kg}$ alüminyum klorür ( $\mathrm{AlC}_{3}$ ) uygulanmasının ardından; üç farklı gruba 21 gün süreyle donepezil, erken hasat sızma zeytinyağı (EVOO) ve rosmarinik asit tedavi protokolleri uygulanmıştır. $\mathrm{Bu}$ çalışmada, oral gavaj ile $\mathrm{AlCl}_{3}$ uygulamasından 15 gün sonra bilişsel bozulmanın ortaya çıtığı ve tedavi protokollerinin histopatolojik olarak AH patolojisinin ortaya çıkmasını engellediğini görülmüştür. Serum ve hipokampusta da oksidatif hasar bulguları olan Congo-red pozitif boyanmış hücre sitoplazması ve bozulmuş hücre bütünlügü gösterilmiştir. Ayrıca, tedavi grupları daha iyi bilişsel ve motor performans göstermiş, kontrol ve tedavi gruplarındaki hücrelerde hasara rastlanmamıştır. Rotarod motor performans testinde donepezil grubunda 26 ve 30 rpm hızlarda $\mathrm{AlCl}_{3}$ grubuna göre anlamlı artış gözlenmiştir. MWM testinde deneyin 5. gününde donepezil grubu, platformun bulunduğu alanda $\mathrm{AlCl}_{3}$ grubuna göre anlamlı olarak daha fazla zaman geçirdiği gösterilmiştir. Bu sonuçlar, 15 günlük alüminyum maruziyetinin 1lımlı AH patolojisi oluşturmada etkili olduğunu göstermektedir ancak rosmarinik asit ve EVOO’nun tedavideki etkinliklerini açıklamak için daha fazla kronik araştırmaya ihtiyaç duyulmaktadır.

Anahtar sözcükler: Alüminyum klorür, Alzheimer, donepezil, EVOO, rosmarinik asit. 


\section{Introduction}

Alzheimer's disease (AD) is the most common neurodegenerative disorder with a gradual deterioration in cognitive function, leading to reduced quality of life in humans (41). $\mathrm{AD}$ is the most common neuropathological form of dementia and characterized by senile plaques and neurofibrillary tangle lesions in the brain, mostly formed by the accumulation of $\beta$-amyloid $(A \beta)$ and hyperphosphorylated tau protein (37). Early identification of risk factors for $\mathrm{AD}$ will allow early diagnosis of the disease and therefore, develop successful treatment strategies (13). Although metals such as aluminum, copper, zinc, lead, mercury, and iron cause neurotoxicity, it has been reported that aluminum ( $\mathrm{Al}$ ) metal is the biggest risk factor for the cause and development of $\mathrm{AD}$ (12). Aluminum accumulates in the cortex, cerebellum, and hippocampus, which are responsible for memory and cognition (36). It has been shown in many studies that chronic aluminum chloride $\left(\mathrm{AlCl}_{3}\right)$ application is used as an $\mathrm{AD}$ model in rodents $(22,29)$.

Currently, there is no drug group or treatment method that can fully treat $\mathrm{AD}$; however, to increase the welfare of the individuals who have the disease, dietary adjustments or treatment programs with certain drugs are implemented. Acetylcholinesterase enzyme inhibitor (AChEI) is one of the frequently preferred groups used in drug treatment. AChEI's act by preventing enzymatic degradation and are seen as first-line treatment options for AD. AChEI group drugs act without changing the development of the underlying pathology, relieving the symptoms and increasing the patient's quality of life and are considered "symptomatic drugs" $(18,43)$. Donepezil, which is still preferred as the first choice for AD treatment, remains popular due to its low toxicity and good tolerability (44). Oxidative stress is considered to be one of the most important causes of pathological phenomena, such as aging and $\mathrm{AD}$ in humans (19). Therefore, the interest of researchers working in this field are: directed more towards natural foods containing high levels of antioxidants recently. Among them, extra-virgin olive oil (EVOO) has an important place. EVOO is an essential component of the Mediterranean diet and has been associated with a long healthy life. EVOO is a complex mixture with $98 \%$ fatty acids esterified with mono and diglycerols and $2 \%$ non-saponified components (14). Despite our knowledge of EVOO phenol's protective role in different pathologies, few studies describe the molecular mechanisms that show how olive oil affects longevity. Studies in rodents have shown that animals fed a diet containing high polyphenols increased cognitive ability and reversed oxidative damage in the brain (31). Another phenol carboxylic acid derivative known to have antioxidant effects is rosmarinic acid (RA); which is in various foods and plants. RA contains antioxidant, antiinflammatory, anti-apoptotic and neuroprotective phenolic compounds (30).

In this study, we aimed to investigate the effects of EVOO, rosmarinic acid, and donepezil on behavioral paradigms and the therapeutic effects of substances in the prefrontal cortex and hippocampus of rats in the Alzheimer's model to be created with $\mathrm{AlCl}_{3}$ administration.

\section{Materials and Methods}

Subjects: Thirty-five adult male Sprague Dawley rats (300-350 gr) were used in this study. All rats were housed in pairs in cages with free access to water and laboratory chow. They were kept in a $12 \mathrm{~h}$-light/12h-dark cycle at constant room temperature $\left(22 \pm 1^{\circ} \mathrm{C}\right)$ and humidity (60\%). Dokuz Eylül University Animal Experiments Local Ethics Committee approved all experimental procedures (Ethics committee approval date: 14.12.2017 decision number: 25/2017).

Experimental Design: 35 healthy male Sprague Dawley rats were divided into five groups: control group, $\mathrm{AlCl}_{3}$ group, donepezil group, EVOO group, and rosmarinic acid group ( $\mathrm{n}=7$ in each group). Physiological saline (PS) was administered to the control group at a dose of $1 \mathrm{ml}$ orally once a day during the study. $\mathrm{AlCl}_{3}$ was obtained from the chemical named $\mathrm{AlCl}_{3}$ Aluminum chloride Anhydrous (Sigma-Aldrich CAS number: 744670-0). $\mathrm{AlCl}_{3}$ was administered orally at a dose of 100 $\mathrm{mg} / \mathrm{kg}$ for 15 days to the animals once a day to induce cognitive impairment (24). Donepezil was obtained from the drug (Pfizer ARICEPT $\quad{ }^{\circledR} \quad 10 \quad \mathrm{mg}$ donepezil hydrochloride) equivalent to $9.12 \mathrm{mg}$ donepezil as the active ingredient frequently preferred at the onset of $\mathrm{AD}$. Donepezil was administered orally at a dose of $5 \mathrm{mg} / \mathrm{kg}$ once a day to the animals (5). EVOO; supplied from oral preparation (Cardiolive, TUAY, TURKEY). $1 \mathrm{ml}$ of EVOO was administered orally to the animals once a day for 1 day (27). Rosmarinic acid was obtained from rosemary juice (Arifoğlu $($ )). It is obtained from the aboveground parts of the rosemary plant by the method of water vapor distillation. Rosmarinic acid was administered orally at a dose of $1 \mathrm{ml}$ once a day for 21 days to be used in animals (35). At the end of the 5 weeks, learning and memory were assessed by Morris Water Maze, anxiety was assessed by open field and elevated plus maze tests. Motor functions assessed by rotarod motor performance test. Animals were euthanized under carbon dioxide anesthesia, blood samples were obtained drawing all intracardiac blood, and brain tissues were removed rapidly. The right hemisphere of the brain was placed in $10 \%$ formol for histological examination, while the other hemisphere was separated from the hippocampus 
and prefrontal cortex. Homogenate and supernatant were prepared from these separated pieces for biochemical analysis. The thymus and adrenal gland tissues of the rats were also removed and their weight was recorded. Relative adrenal and thymus weight adrenal weight/body weight ratio; calculated by thymus weight/body weight ratio.

Morris Water Maze Test (MWM): Learning experiments were conducted using Morris water maze test. By placing signs such as a clock and a painting on the room walls where the pool is located, rats were allowed to determine their direction using these signs. A video camera system was installed to monitor and record rats's behavior at an average height of $2 \mathrm{~m}$ from the center of the tank. On each test day, rats were placed in the water facing the pool edge from one of the 3 randomly selected quadrants without the hidden platform and allowed to swim until they found the hidden platform. Maximum swimming time was limited to 60 seconds. If the rat could not find the platform within 60 seconds, the rat placed on the for 15 seconds after the try. Each rat was subjected to five consecutive experiments per day, with intervals of 60 seconds. After completing each experiment, the rats were taken from the platform, dried, and placed in their cages. These procedures were repeated for 4 consecutive days. Thus, a total of 20 experiments was applied to each rat for 4 days. On day 5 , a probe trial was applied to each rat. The platform was removed from the pool, and the rat was allowed to swim for 60 seconds. Behavioral data were evaluated using the HVS image video tracking system as swimming distance, time to find the platform, and the time spent in each quadrant (39).

Open Field Test (OF): This test is commonly used to assess spontaneous locomotor activity and anxiety. The open field consists of a $1 \times 1 \mathrm{~m}$ area surrounded by a wall of $50 \mathrm{~cm}$ in height. A video camera was installed $2.5 \mathrm{~m}$ above the apparatus. Each rat was placed in the center of the open field, and locomotor activity was measured for $5 \mathrm{~min}$ in a soundproof observation room, illuminated with controlled light (1001x) (7).

Elevated Plus Maze (EPM): The elevated plus maze is another commonly used experimental rodent model to assess anxiety. The elevated plus maze apparatus consists of a central platform $(5 \mathrm{~cm} \times 5 \mathrm{~cm})$ with two open arms ( $50 \mathrm{~cm}$ long, $10 \mathrm{~cm}$ wide and $0.5 \mathrm{~cm}$ high borders) and two closed arms (50 cm long, $10 \mathrm{~cm}$ wide with $40 \mathrm{~cm}$ high walls), each elevated $50 \mathrm{~cm}$ above the floor. Rats were placed on the platform facing the open arm and were observed for $5 \mathrm{~min}$. The total number of entries into the open and closed arms, as well as the entire time spent on the open and closed arms was measured (15).

Rotarod Test (RT): The rotarod test setup enables the evaluation of motor performance by measuring balance, coordination, and motor control. The apparatus measures the rodent's ability to stand on a rotating shaft at a certain speed or with increasing speed. In the speedincreased protocol, graded speeds between 4-40 rpm are tried in each trial. The test, which was applied for 300 seconds, it was started with a speed of $16 \mathrm{rpm}$ and measurements were made gradually at 20, 26, and $30 \mathrm{rpm}$. In the five-lane set-ups, two rats were tested simultaneously. With the help of the mechanism with a timer on the floor, how long the rat can stand on the shaft without falling down at any speed was measured, and the speed it fell for the consequent three times was recorded as the maximum speed it could walk (2).

Biochemical Analysis: Blood and all tissue samples were stored at $-85^{\circ} \mathrm{C}$. Acetylcholinesterase (AChE), lactate dehydrogenase (LDH) enzyme levels by spectrophotometric method (Fully automated Roche/ Hitachi cobas c501). Malondialdehyde (MDA) levels were analyzed by Bioassay Technology Laboratory Rat MDA ELISA Kit (catalog no: E0156Ra, Shanghai, ChinaAssay sensitivity $0.01 \mathrm{nmol} / \mathrm{ml}$ and detection range is $0.05-10 \mathrm{nmol} / \mathrm{ml}$ ). A $\beta-42$ precursor protein accumulation was analyzed by Bioassay Technology Laboratory Rat Soluble Amyloid Precursor Protein Beta ELISA Kit (catalog number: E01010Ra, Shanghai, China-Assay sensitivity $0.053 \mathrm{ng} / \mathrm{ml}$ and its detection 01-40 ng $/ \mathrm{ml}$ ). BCA protein Assay kit (Cat No: E- BP-500, Elabscience, Wuhan, China) was used for protein analyses, according to the manufacturers' description. Serum corticosterone (CORT) levels were analyzed Bioassay Technology Laboratory CORT - Rat ELISA kit (catalog no: E0496Ra, Shanghai, China-Assay sensitivity $0.24 \mathrm{ng} / \mathrm{ml}$, detection range $0.5 \mathrm{ng} / \mathrm{ml}-100 \mathrm{ng} / \mathrm{ml}$ ). Protein and serum CORT levels were measured in the hippocampus, prefrontal cortex homogenates, and serum.

Histological Analysis: Hematoxylin-Eosin (HE) staining of brain tissue samples taken from all groups was performed following the hematoxylin (HX86017674, Merck Hematoxylin, Darmstadt, Germany) protocol and congo red staining (ChemBio laboratory research) protocol.

Statistical Evaluation: All statistical procedures were performed by SPSS software for Windows, Version 23.0 (SPSS, Chicago, IL). Descriptive statistics for each variable were calculated. Prior to hypothesis testing, data were examined with Shapiro- Wilk test for normality and Levene test for homogeneity of variances as parametric test assumptions. Differences between groups were analyzed using one-way ANOVA for data that provide parametric test assumptions. Bonferroni test was used as post hoc. Kruskal Wallis test was used to examine the differences among the groups for the variables that violates parametric test assumptions. Dunn-Bonferroni 
test was used as post hoc analysis. A value of $\mathrm{P}<0.05$ was considered to be statistically significant.

\section{Results}

Histopathologically, H\&E staining showed atrophy, decreased neuronal cell density, and gliosis in the prefrontal cortex in the Alzheimer group compared to the control group. Similarly, in H\&E staining in the hippocampus, the neuronal cell density in the Alzheimer group compared to the control group decreased, and gliosis was observed (Figure 1. A). Also, neurofibrillary tangles were found in the cytoplasm of cells in basophilic staining in the Alzheimer group (Figure 1. B). Congo red staining showed positively stained cell cytoplasm and impaired cell integrity in the hippocampus and prefrontal cortex of the Alzheimer's group (Figure 1. C). There was no damage to the cells in the control and treatment groups.

There was no significant difference between the groups in the analyzes of the prefrontal cortex MDA, LDH, cholinesterase, and sAppBeta (Table 1 and Table 2). The hippocampus LDH level was found to be significantly lower in the $\mathrm{AlCl}_{3}$ group compared to the control group (Table 1). There was no significant difference in serum CORT level between the groups, serum MDA and cholinesterase level in the $\mathrm{AlCl}_{3}$ group compared to the control group (Table 1), serum LDH level in the $\mathrm{AlCl}_{3}$ group (Table 1) were significantly higher than all groups.

The relative thymus weight showed a significant decrease in the $\mathrm{AlCl}_{3}$ group compared to the control group, and a significant increase in the treatment groups compared to the control group. There was no significant difference between relative adrenal weights (Table 3).

There was no significant difference between groups in the OF (Table 4) and EPM (Table 5). In the rotarod motor performance test, a significant increase was observed in the donepezil group compared to the $\mathrm{AlCl}_{3}$ group at speeds of 26 and $30 \mathrm{rpm}$. At speeds of 16 and 20 rpm, all groups showed better walking performance compared to $\mathrm{AlCl}_{3}$ group (Table 6). In MWM, an increase in swimming speed was observed in the $\mathrm{AlCl}_{3}$ group on the $3^{\text {rd }}$ and $4^{\text {th }}$ learning days compared to the control group (Table 7 ). On the $5^{\text {th }}$ day of the experiment, a significant increase was observed in the donepezil group compared to the $\mathrm{AlCl}_{3}$ group, as they were spending more time in the hidden platform area (Table 8). EVOO and rosmarinic acid groups also spent more time in the hidden platform area compared to the $\mathrm{AlCl}_{3}$ group as shown in Table 7 .

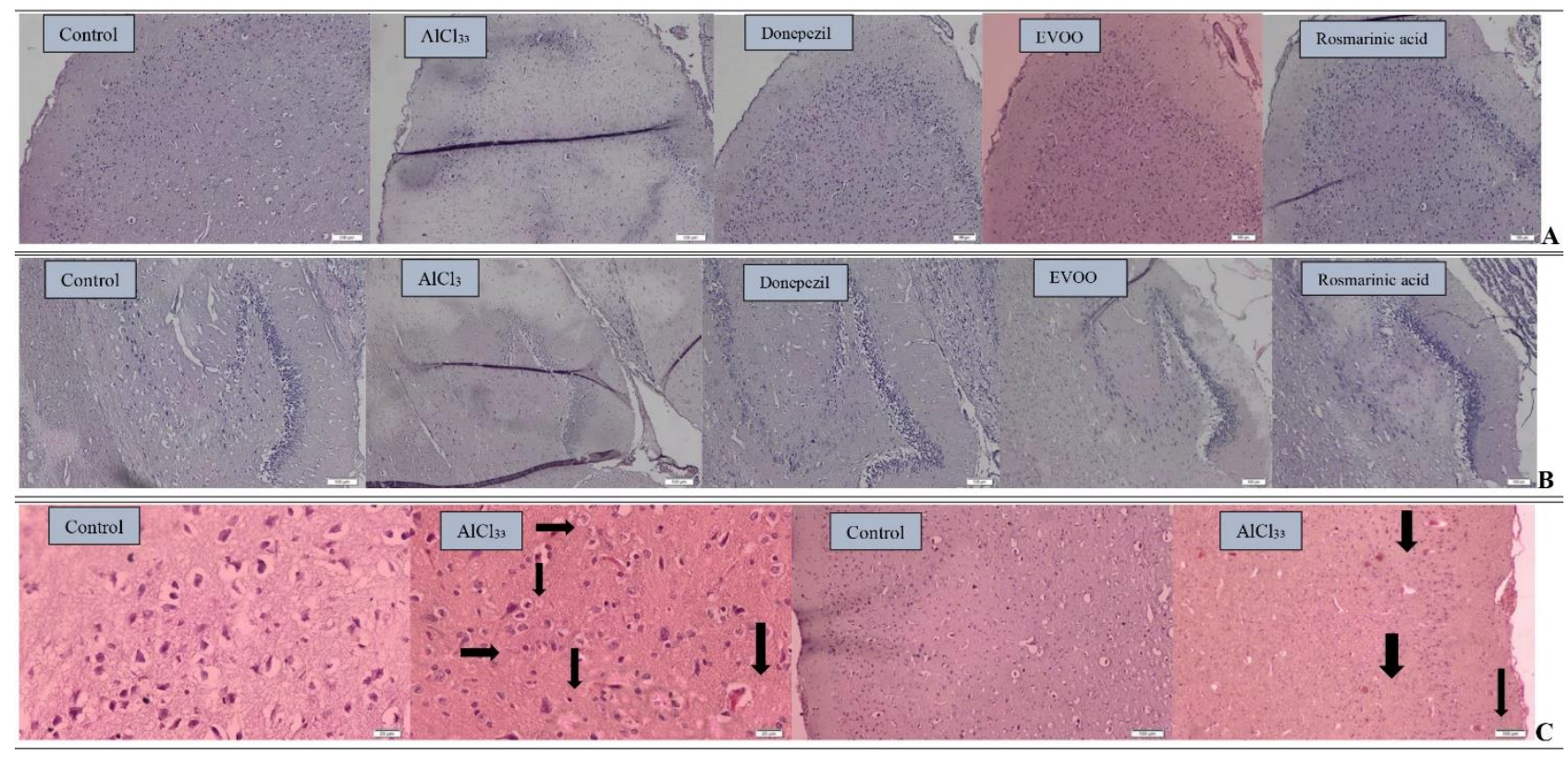

Figure 1. Histopathology results.

A. H\&E staining in the prefrontal cortex (x100). B. H\&E staining in the hippocampus (x100). C. Congo red staining in hippocampus (x400) and prefrontal cortex (x100). 


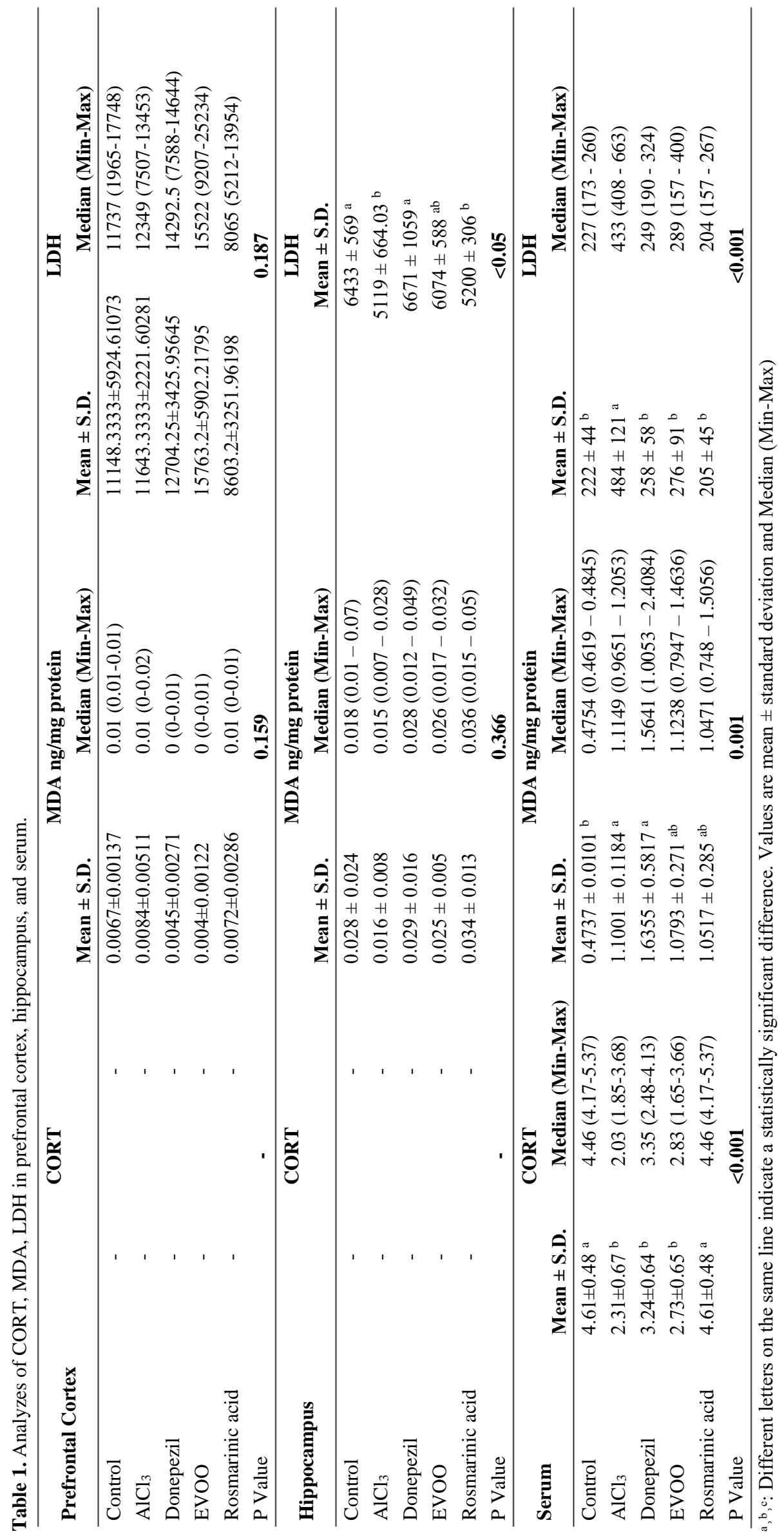


Table 2. Analyzes of cholinesterase, and sAppBeta in prefrontal cortex, hippocampus, and serum.

\begin{tabular}{lllll}
\hline \multirow{2}{*}{ Prefrontal Cortex } & \multicolumn{2}{c}{ sAppbeta ng/mg protein } & \multicolumn{2}{c}{ Cholinesterase } \\
& Mean \pm S.D. & Median (Min-Max) & Mean \pm S.D. & Median (Min-Max) \\
\hline Control & $0.1477 \pm 0.03227$ & $0.15(0.11-0.19)$ & $94 \pm 52.78257$ & $110(28-150)$ \\
$\mathrm{AlCl}_{3}$ & $0.1754 \pm 0.0531$ & $0.16(0.12-0.25)$ & $106.1667 \pm 24.9593$ & $104.5(80-145)$ \\
Donepezil $_{\text {EVOO }}$ & $0.1675 \pm 0.10917$ & $0.14(0.06-0.32)$ & $101 \pm 38.02631$ & $102.5(53-146)$ \\
Rosmarinic acid & $0.0933 \pm 0.03645$ & $0.1(0.04-0.13)$ & $312.4 \pm 471.62623$ & $103(92-1156)$ \\
P Value & $0.1597 \pm 0.10184$ & $0.14(0.07-0.33)$ & $55.6 \pm 29.2113$ & $45(36-107)$ \\
\hline
\end{tabular}

\begin{tabular}{|c|c|c|c|c|}
\hline \multirow{2}{*}{ Hippocampus } & \multicolumn{2}{|c|}{ sAppbeta ng/mg protein } & \multicolumn{2}{|c|}{ Cholinesterase } \\
\hline & Mean \pm S.D. & Median (Min-Max) & Mean \pm S.D. & Median (Min-Max) \\
\hline Control & $0.2821 \pm 0.1222$ & $0.2566(0.1452-0.4455)$ & $41 \pm 27$ & $48(1-73)$ \\
\hline $\mathrm{AlCl}_{3}$ & $0.2821 \pm 0.1222$ & $0.2566(0.1452-0.4455)$ & $41 \pm 27$ & $48(1-73)$ \\
\hline Donepezil & $0.3873 \pm 0.2$ & $0.406(0.1478-0.5893)$ & $34 \pm 24$ & $31(9-67)$ \\
\hline EVOO & $0.3104 \pm 0.0977$ & $0.3132(0.2077-0.4291)$ & $36 \pm 23$ & $35(9-69)$ \\
\hline Rosmarinic acid & $0.4916 \pm 0.3466$ & $0.4559(0.1733-1.0575)$ & $13 \pm 8$ & $11(3-22)$ \\
\hline P Value & & 0.406 & & \\
\hline \multirow{2}{*}{ Serum } & \multicolumn{2}{|c|}{ sAppbeta ng/mg protein } & \multicolumn{2}{|c|}{ Cholinesterase } \\
\hline & Mean \pm S.D. & Median (Min-Max) & Mean \pm S.D. & Median (Min-Max) \\
\hline Control & $1.1896 \pm 0.188$ & $1.2999(0.935-1.3471)$ & $151 \pm 36$ & $136(114-197)$ \\
\hline $\mathrm{AlCl}_{3}$ & $0.9961 \pm 0.2956$ & $0.8932(0.6542-1.3939)$ & $202 \pm 64$ & $201(137-292)$ \\
\hline Donepezil & $1.1294 \pm 0.2122$ & $1.2205(0.7918-1.3392)$ & $140 \pm 32$ & $128(110-190)$ \\
\hline EVOO & $0.9765 \pm 0.2926$ & $1.0506(0.5227-1.2285)$ & $137 \pm 34$ & $136(88-180)$ \\
\hline Rosmarinic acid & $1.079 \pm 0.2706$ & $1.1644(0.7747-1.3392)$ & $130 \pm 18$ & $121(113-155)$ \\
\hline P Value & & 0.658 & \multicolumn{2}{|c|}{0.061} \\
\hline
\end{tabular}

a,b: Different letters on the same line indicate a statistically significant difference. Values are mean \pm standard deviation and Median (Min-Max).

Table 3. The relative adrenal and thymus weights in the all groups.

\begin{tabular}{|c|c|c|c|c|}
\hline \multirow{2}{*}{ Groups } & \multicolumn{2}{|c|}{ Relative Adrenal Weight } & \multicolumn{2}{|c|}{ Relative Thymus Weight } \\
\hline & Mean \pm S.D. & Median (Min-Max) & Mean \pm S.D. & Median (Min-Max) \\
\hline Control & $0.0236 \pm 0.0064$ & $0.0202(0.0189-0.0355)$ & $0.0564 \pm 0.0073^{b}$ & $0.0567(0.047-0.0665)$ \\
\hline $\mathrm{AlCl}_{3}$ & $0.0161 \pm 0.003$ & $0.0166(0.0113-0.0198)$ & $0.0363 \pm 0.008^{c}$ & $0.036(0.0249-0.0473)$ \\
\hline Donepezil & $0.0202 \pm 0.0074$ & $0.0184(0.0118-0.0333)$ & $0.0833 \pm 0.0133^{\mathrm{a}}$ & $0.0763(0.075-0.1064)$ \\
\hline EVOO & $0.0192 \pm 0.0067$ & $0.0176(0.0118-0.03)$ & $0.086 \pm 0.0076^{\mathrm{a}}$ & $0.085(0.0772-0.1)$ \\
\hline Rosmarinic Acid & $0.0213 \pm 0.0022$ & $0.0208(0.018-0.0242)$ & $0.0711 \pm 0.0065^{a b}$ & $0.0711(0.0625-0.0783)$ \\
\hline $\mathrm{P}$ & & 0.166 & & $<0.001$ \\
\hline
\end{tabular}

$\overline{a, b}, \mathrm{c}:$ Different letters on the same line indicate a statistically significant difference. Values are mean \pm standard deviation and Median (Min-Max). 

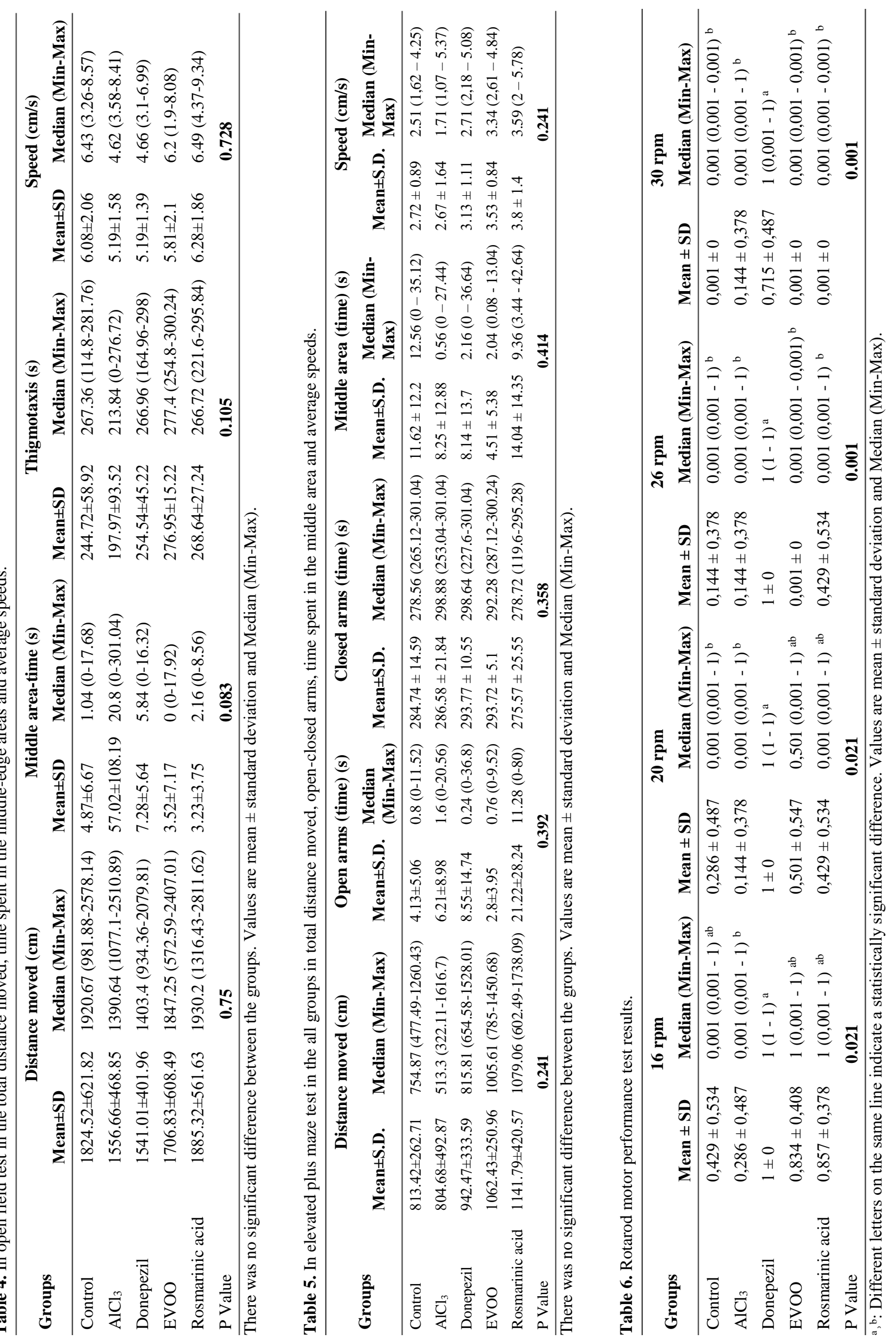
Table 7. In MWM, an increase in swimming speed observed in the all group on the $3^{\text {rd }}$ and $4^{\text {th }}$ learning days.

\begin{tabular}{lcccc}
\hline Groups & 1.day & 2.day & 3.day & 4.day \\
\hline Control & $21.07 \pm 1.47$ & $18.67 \pm 2.95$ & $16.44 \pm 3.07^{\mathrm{a}}$ & $19.56 \pm 1.89^{\mathrm{a}}$ \\
$\mathrm{AlCl}_{3}$ & $21.92 \pm 2.23$ & $20.47 \pm 4.20$ & $34.93 \pm 10.64^{\mathrm{b}}$ & $27.55 \pm 5.62^{\mathrm{b}}$ \\
Donepezil & $21.69 \pm 2.46$ & $20.79 \pm 5.19$ & $20.12 \pm 3.29^{\mathrm{a}, \mathrm{b}}$ & $21.58 \pm 6.71^{\mathrm{a}, \mathrm{b}}$ \\
EVOO & $21.19 \pm 3.05$ & $21.49 \pm 3.66$ & $27.45 \pm 9.12^{\mathrm{a}, \mathrm{b}}$ & $16.62 \pm 4.09^{\mathrm{a}, \mathrm{b}}$ \\
Rosmarinic acid & $20.18 \pm 4.245$ & $23.01 \pm 7.09$ & $30.16 \pm 5.64^{\mathrm{a}, \mathrm{b}}$ & $18.37 \pm 2.88^{\mathrm{a}, \mathrm{b}}$ \\
\hline
\end{tabular}

a, $b$ :Different letters on the same line indicate a statistically significant difference $(\mathrm{P}<0.05)$. Values are mean \pm standard deviation.

Table 8. On the $5^{\text {th }}$ day of the experiment spending time in the hidden platform area in the all group.

\begin{tabular}{lccccc}
\hline Groups & $\begin{array}{c}\text { Hidden platform area } \\
(\text { time) }(\mathbf{s})\end{array}$ & $\begin{array}{c}\text { Other platforms } \\
(\text { time })(\mathbf{s})\end{array}$ & Distance swim $(\mathbf{c m})$ & $\begin{array}{c}\text { Swim speed } \\
(\mathbf{c m} / \mathbf{s})\end{array}$ & Thigmotaxis $(\mathbf{s})$ \\
\hline Control & $23.89 \pm 4.52^{\mathrm{a}} \mathrm{b}^{\mathrm{b}}$ & $11.31 \pm 1.73$ & $1604.82 \pm 128.51$ & $27.10 \pm 2.10$ & $21.15 \pm 6.28$ \\
$\mathrm{AlCl}_{3}$ & $19.80 \pm 3.37^{\mathrm{a}}$ & $13.59 \pm 1.09$ & $1227.42 \pm 148.53$ & $20.27 \pm 2.63$ & $31.08 \pm 10.40$ \\
Donepezil & $31.89 \pm 9.051^{\mathrm{b}}$ & $10.19 \pm 3.31$ & $1207.3 \pm 263.33$ & $19.77 \pm 4.31$ & $24.11 \pm 6.73$ \\
$\mathrm{EVOO}$ & $27.52 \pm 3.32^{\mathrm{a}}, \mathrm{b}$ & $11.17 \pm 1.10$ & $1335.89 \pm 246.51$ & $20.51 \pm 4.03$ & $21.98 \pm 12.28$ \\
Rosmarinic acid & $28.49 \pm 6.62^{\mathrm{a}}, \mathrm{b}$ & $10.06 \pm 1.84$ & $1376.38 \pm 230.69$ & $23.57 \pm 4.53$ & $22.29 \pm 2.25$ \\
\hline
\end{tabular}

a, $\mathbf{b}$ : Different letters on the same line indicate a statistically significant difference $(\mathrm{P}<0.05)$. Values are mean \pm standard deviation.

\section{Discussion and Conclusion}

In this study, we were able to demonstrate that cognitive impairment has been occurred after 15 days of $\mathrm{AlCl}_{3}$ administration by oral gavage and treatment protocols prevented the occurrence of $\mathrm{AD}$ pathology histopathologically. We also showed that oxidative damage findings have been observed in serum and hippocampus. Besides, treatment groups showed better cognitive and motor performance, and there was no damage to the cells in the control and treatment groups.

Neuropathologically, extracellular $\beta$-amyloid plaque deposition, intracellular neurofibrillary tangle deposition, neuron and synapse loss, basal forebrain, hippocampus, and gliosis in learning-related regions are the histopathological findings for $\mathrm{AD}$ (9). In a study in which $100 \mathrm{mg} / \mathrm{kg} \mathrm{AlCl} \mathrm{Al}_{3}$ was administered orally to rats, pathological changes were not observed in the control group, while vacuolated cytoplasm, neurodegeneration, and inflammation were shown in the $\mathrm{AlCl}_{3}$ group (22). Consistent with the studies in the literature, in this study, hematoxylin\&eosin staining showed atrophy, decreased neuronal cell density, and gliosis in the prefrontal cortex and hippocampus of rats in the $\mathrm{AlCl}_{3}$ group to compare control group. In the hippocampus, neurofibrillary tangles in the form of basophilic staining were also detected in the $\mathrm{AlCl}_{3}$ group, unlike the control group. In congo red staining, positively stained cell cytoplasms and degenerations were found in the prefrontal cortex and hippocampus in the $\mathrm{AlCl}_{3}$ group, unlike the control group.

Oxidative stress is defined as the imbalance between reactive oxygen/nitrogen species (ROS/RNS) and the capacity of anti-oxidative protection systems of cells to neutralize these reagents (32). Recent evidence indicates that some oxidation products act as biomarkers in some neurodegenerative diseases, and the lipid peroxidation product malondialdehyde (MDA) is one of them (3). Increased MDA levels are observed in the cortex and hippocampus in Alzheimer's patients (3), but no significant difference between groups was observed in the tissue level in this study. This may be because the $\mathrm{AlCl}_{3}$ application was performed for 15 days, and this period did not cause oxidative stress at the tissue level. However, serum MDA level was significantly higher in the $\mathrm{AlCl}_{3}$ group compared to the control group, which can be interpreted as the onset of oxidative stress changes in the $\mathrm{AlCl}_{3}$ group.

Lactate dehydrogenase (LDH) is an enzyme found in almost every cell and tissue in the body. The high total activity in the LDH enzyme indicates tissue damage or cell destruction in the body (23). In a study that using the model induced by $\mathrm{AlCl}_{3}$, it was found that the serum $\mathrm{LDH}$ level of the $\mathrm{AlCl}_{3}$ group was significantly higher than the control and treatment groups (19). Interestingly, some studies using an Alzheimer's mouse model suggest that the loss of aerobic glycolysis in the brain is associated with AD. In a study conducted with APP/PS1 mice, it was shown that there was a decrease in the expression of the aerobic glycolysis kinase isoenzyme 1 (PDK1) and LDH enzyme in the frontal cortex compared to the same age group control mice at the age of 12 months (28). Besides, brain imaging studies in humans have shown that the brain regions most sensitive to amyloid toxicity are in the regions where aerobic glycolysis is at the highest level (42). This situation is defined as a protective mechanism 
against $A \beta$ accumulation, and it is accepted that the loss of this mechanism triggers AD (40). In this study, consistent with the results in the literature, it was observed that the serum $\mathrm{LDH}$ level of the $\mathrm{AlCl}_{3}$ group was significantly higher than the control and treatment groups, and the LDH activity in the hippocampus was significantly lower in the $\mathrm{AlCl}_{3}$ group than in the other groups. This result can be considered an indicator that a moderate level of Alzheimer's pathology has begun to occur.

In recent studies, the ratio of organ weight to body weight is considered the most widely used index to show stress-induced organ weight changes. Accordingly, absolute thymus weight can be used as biological indicators generated in response to stress (16). In this study, no statistically significant difference was found in the relative adrenal weights of the control, Alzheimer's, and treatment groups. However, a significant decrease was observed in the relative thymus weights in the $\mathrm{AlCl}_{3}$ group compared to the control group, and a statistically significant increase was observed in the donepezil and EVOO treatment groups compared to the control group. In human, animal, and in vitro studies, it has been shown that phenolic compounds in EVOO are antioxidant molecules that can scavenge the toxic effects of oxygen metabolism, such as free radical formation, and thus protect cells against oxidative damage (25). Donepezil also shows significant effectiveness in reducing the severity of neuropsychiatric symptoms in mild to moderate AD (11). According to the results of this study, results are consistent with the conclusion in the literature that the use of EVOO and donepezil reduces the negative effects of stress.

Cognitive impairment is the main clinical symptom of $\mathrm{AD}$; however, non-cognitive problems such as motor dysfunctions are also associated with the disease $(6,33)$. The decline in motor skills in mild to moderate Alzheimer's patients is substantial than in patients with moderate and severe periods (45). Recent studies suggest that AChEI's may improve some of these changes (4). In another study, it was reported that donepezil in Alzheimer's patients did not have any positive effect on motor functions (17). Also, in another study, enriching the diet with herbal antioxidants can improve brain damage and cognitive functions (30). The anti-amnesic activation effect of rosmarinic acid against neurotoxicity and neurodegeneration induced by $A \beta$ in mice was also shown $(20,26)$. But in this study, in the rotarod motor performance test, there was a statistically significant difference between donepezil and the other groups at 26 and $30 \mathrm{rpm}$ speeds and showed better walking performance. Studies on the effect of donepezil on motor performance in the literature are limited, and more research is needed on this subject.

MWM test is one of the most important methods that can be used to evaluate learning and memory in experimental animals with an Alzheimer's model (38). In a study, administration D-galactose and $\mathrm{AlCl}_{3}$ in rats reported that the donepezil treated group found the hidden platform, and the swimming distance was significantly shorter than the $\mathrm{AlCl}_{3}$ group (8). In this study, consistent with the results in the literature, it was observed that the time spent on the platform hidden area on the 5th day of the experiment was significantly higher in the donepezil group than the $\mathrm{AlCl}_{3}$ group. Increased swimming speed in the MWM is considered one of the indicators of increased anxiety. In a study shown that the platform finding time of mice with Alzheimer's pathology took longer than the control group, and at the same time, the swimming speed increased compared to the control group (21). Again, in a study in which $3 x \mathrm{Tg}$-AD mice were used, control mice were more comfortable swimming; it has been observed that mice with Alzheimer's are more stressed and faster (10). As shown in the literature, MWM measures not only spatial learning but also anxiety and sensorimotor skills (1). In this study, it was observed that the swimming speed of the $\mathrm{AlCl}_{3}$ group increased significantly on the $3^{\text {rd }}$ and $4^{\text {th }}$ days of the learning experiment compared to the control group. This situation is consistent with the results of increased anxiety and prolonged platform finding in animals with mild Alzheimer's pathology, as stated in the literature.

In OF, avoiding the middle area is considered as an indicator of anxiety. Thigmotaxis is defined as the desire to spend time near the wall, and it is accepted that animals displaying anxiety-like behavior show this behavior more frequently (34). In this study, there was no difference between the groups in OF and EPM. This result can be interpreted as that the disease-inducing and treatment protocols applied to all groups for 5 weeks may cause similar anxiety.

In conclusion, these studies results show that 15 days of aluminum exposure is effective in creating a moderate Alzheimer's pathology, but further chronic researches are necessary to explain efficiencies of rosmarinic acid and EVOO in treatment.

\section{Acknowledgement}

This study is produced from the first author's $\mathrm{PhD}$ thesis.

\section{Finacial support}

This research received no grant from any funding agency/sector.

\section{Ethical Statement}

This study was approved by the Animal Experiments Local Ethics Committee of Dokuz Eylül University (Ethics committee approval date: 14.12.2017 Decision number: 25/2017). 


\section{Conflict of Interest}

The authors have no conflict of interests to disclose.

\section{References}

1. Abbas T, Faivre E, Hölscher C (2009): Impairment of synaptic plasticity and memory formation in GLP-1 receptor KO mice: Interaction between type 2 diabetes and Alzheimer's disease. Behav Brain Res, 205, 265-271.

2. Bazrgar M, Goudarzi I, Lashkarbolouki T, et al (2015): Melatonin ameliorates oxidative damage induced by maternal lead exposure in rat pups. Physiol Behav, 151, 178-188.

3. Bhat AH, Dar KB, Anees S, et al (2015): Oxidative stress, mitochondrial dysfunction and neurodegenerative diseases; a mechanistic insight. Biomed Pharmacother, 74, 101-110.

4. Birks J (2006): Cholinesterase inhibitors for Alzheimer's disease. Cochrane Database Syst Rev, 25, CD005593.

5. Biswas J, Gupta S, Verma DK, et al (2018): Involvement of glucose related energy crisis and endoplasmic reticulum stress: Insinuation of streptozotocin induced Alzheimer's like pathology. Cell Signal, 42, 211-226.

6. Camicioli R, Bouchard T, Licis L (2006): Dual-tasks and walking fast: relationship to extra-pyramidal signs in advanced Alzheimer disease. J Neurol Sci, 248, 205-209.

7. Casarrubea M, Sorbera F, Crescimanno G (2009): Multivariate data handling in the study of rat behavior: an integrated approach. Behav Res Methods, 41, 772-781.

8. Chiroma SM, Baharuldin MTH, Taib M, et al (2019): Protective effects of centella asiatica on cognitive deficits induced by D-gal/AlCl3 via inhibition of oxidative stress and attenuation of acetylcholinesterase level. Toxics, 7, 19.

9. Cotman CW, Head E (2008): The canine (dog) model of human aging and disease: dietary, environmental and immunotherapy approaches. J Alzheimers Dis, 4, 685-707.

10. Davis K, Burnett K, Gigg J (2017): Water and T-maze protocols are equally efficient methods to assess spatial memory in 3xTg Alzheimer's disease mice. Behav Brain Res, 331, 54-66.

11. Doody RS, Geldmacher DS, Gordon B, et al (2001): Open-label, multicenter, phase 3 extension study of the safety and efficacy of donepezil in patients with Alzheimer disease. Archives of Neurology, 58, 427-33.

12. Enas AK (2010): Study of the possible protective and therapeutic influence of Coriander (Coriandrum sativum L.) against neurodegenerative disorders and Alzheimer's disease induced by aluminum chloride in cerebral cortex of male Albino rats. Nat Sci, 8, 202-213.

13. Frisoni GB, Boccardi M, Barkhof F, et al (2017): Strategic roadmap for an early diagnosis of Alzheimer's disease based on biomarkers. Lancet Neurol, 16, 661-676.

14. Genovese A, Caporas ON, Villani V, et al (2015): Olive oil phenolic compounds affect the release of aroma compounds. Food Chem, 181, 284-294.

15. Handley SL, Mithani S (1984): Effects of alphaadrenoceptor agonists and antagonists in a mazeexploration model of 'fear'-motivated behaviour. Naunyn Schmiedebergs Arch Pharmacol, 327, 1-5.

16. Hara C, Manabe K, Ogawa N (1981): Influence of activity-stress on thymus, spleen and adrenal weights of rats: Possibility for an immunodeficiency model. Physiology \& Behavior, 27, 243-8.

17. Hegerl U, Mergl R, Henkel V, et al (2003): Kinematic analysis of the effects of donepezil hydrochloride on hand motor function in patients with Alzheimer dementia. J Clin Psychopharmacol, 23, 214-216.

18. Howes LG (2014): Cardiovascular effects of drugs used to treat Alzheimer's disease. Drug Saf, 37, 391-395.

19. Huang WJ, Zhang X, Chen WW (2016): Role of oxidative stress in Alzheimer's disease. Biomed Rep, 4, 519-522.

20. Iuvone T, De Filippis D, Esposito G, et al (2006): The spice sage and its active ingredient rosmarinic acid protect PC12 cells from amyloid- $\beta$ peptide-induced neurotoxicity. $\mathrm{J}$ Pharmacol Exp, 17, 1143-1149.

21. Kapadia M, XU J, Sakic B (2016): The water maze paradigm in experimental studies of chronic cognitive disorders: Theory, protocols, analysis, and inference. Neurosci Biobehav Rev, 68, 195-217.

22. Lakshmi B, Sudhakar M, Prakash KS (2015): Protective effect of selenium against aluminum chloride-induced Alzheimer's disease: behavioral and biochemical alterations in rats. Biol Trace Elem Res, 165, 67-74.

23. Livesey A, Garty F, Shipman A, et al (2019): Lactate dehydrogenase in dermatology practice. Clin Exp Dermatol, 28, 26-33.

24. Mathiyazahan DB, Thenmozhi AJ, Manivasagam T (2015): Protective effect of black tea extract against aluminium chloride-induced Alzheimer's disease in rats, A behavioural, biochemical and molecular approach. J Funct Foods, 16, 423-435.

25. Montedoro G, Servili M, Baldioli M, et al (1992): Simple and hydrolyzable phenolic compounds in virgin olive oil, Their extraction, separation, and quantitative and semiquantitative evaluation by HPLC. J Agric Food Chem, 40, 1571-1576.

26. Mushtaq N, Schmatz R, Pereira LB, et al (2014): Rosmarinic acid prevents lipid peroxidation and increase in acetylcholinesterase activity in brain of streptozotocin induced diabetic rats. Cell Biochem, 32, 287-293.

27. Nakbi A, Tayeb W, Grissa A, et al (2010): Effects of olive oil and its fractions on oxidative stress and the liver's fatty acid composition in 2, 4-Dichlorophenoxyacetic acidtreated rats. Nutr Metab, 7, 80.

28. Newington JT, Rappon T, Albers S, et al (2012): Overexpression of pyruvate dehydrogenase kinase 1 and lactate dehydrogenase $A$ in nerve cells confers resistance to amyloid $\beta$ and other toxins by decreasing mitochondrial respiration and reactive oxygen species production. $\mathrm{J}$ Biol Chem, 44, 37245-37258.

29. Olajide OJ, Yawson EO, Gbadamosi IT, et al (2017): Ascorbic acid ameliorates behavioural deficits and neuropathological alterations in rat model of Alzheimer's disease. Environ Toxicol Pharmacol, 50, 200-211.

30. Ono K, Li L, Takamura Y, et al (2012): Phenolic compounds prevent amyloid $\beta$-protein oligomerization and synaptic dysfunction by site-specific binding. $\mathrm{J}$ Biol Chem, 287, 14631-14643.

31. Papandreou MA, Dimakopoulou A, Linardaki ZI, et al (2009): Effect of a polyphenol-rich wild blueberry extract on cognitive performance of mice, brain antioxidant 
markers and acetylcholinesterase activity. Behav Brain Res, 198, 352-358.

32. Persson T, Popescu BO, Cedazo-Minguez A (2014): Oxidative stress in Alzheimer's disease: why did antioxidant therapy fail? Oxid Med Cel Longev, Article ID 427318.

33. Pettersson AF, Engardt M, Wahlund LO (2002): Activity level and balance in subjects with mild Alzheimer's disease. Dement Geriatr Cogn, 13, 213-216.

34. Prut L, Belzung C (2003): The open field as a paradigm to measure the effects of drugs on anxiety-like behaviors: a review. Eur J Pharmacol, 463, 3-33.

35. Santos F, Rao V (2000): Antiinflammatory and antinociceptive effects of 1,8 cineole a terpenoid oxide present in many plant essential oils. Phytother Res, 14, 240-244.

36. Shamasundar N, Rao TS, Naidu MD, et al (2006) A new insight on Al-maltolate-treated aged rabbit as Alzheimer's animal model. Brain Res Rev, 52, 275-292.

37. Sperling RA, Aisen PS, Beckett LA, et al (2011): Toward defining the preclinical stages of Alzheimer's disease: Recommendations from the National Institute on AgingAlzheimer's Association workgroups on diagnostic guidelines for Alzheimer's disease. Alzheimers Dement, 7, 280-292.

38. Tian H, Ding N, Guo M, et al (2019): Analysis of Learning and Memory Ability in an Alzheimer's Disease Mouse Model using the Morris Water Maze. JoVE, 152, e60055.
39. Uysal N, Baykara B, Kiray M, et al (2013): Combined treatment with progesterone and magnesium sulfate positively affects traumatic brain injury in immature rats. Turk Neurosurg, 23, 129-137.

40. Valvona CJ, Fillmore HL, Nunn PB, et al (2016): The regulation and function of lactate dehydrogenase a: therapeutic potential in brain tumor. Brain Pathol, 1, 3-17.

41. Vinters HV (2015): Emerging concepts in Alzheimer's disease. Annu Rev Pathol, 10, 291-319.

42. Vlassenko AG, Vaishnavi SN, Couture L, et al (2010): Spatial correlation between brain aerobic glycolysis and amyloid- $\beta$ (Aß) deposition. Proc Natl Acad Sci, 41, 1776317767.

43. Winblad B, Engedal K, Soininen H, et al (2001): A 1-year, randomized, placebo-controlled study of donepezil in patients with mild to moderate AD. Neurology, 57, 489-495.

44. Wu M-Y, Esteban G, Brogi S, et al (2016): Donepezil-like multifunctional agents: design, synthesis, molecular modeling and biological evaluation. Eur J Med Chem, 121, 864-79.

45. Zidan M, Arcoverde C, Araújo NB, et al (2012): Alterações motoras e funcionais em diferentes estágios da doença de Alzheimer. Arch Clin, 39, 161-165. 